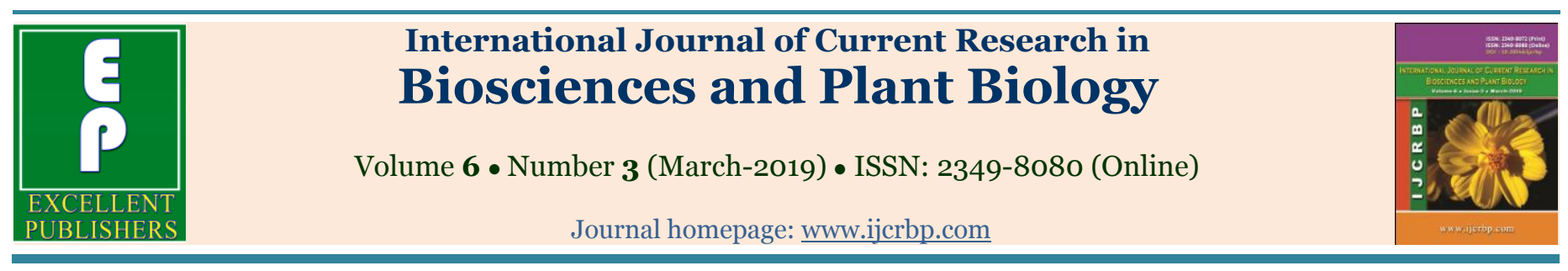

\title{
Molecular genetic identification of viruses affecting pepper crop (Capsicum spp.) in Western North of Benin
}

\author{
André Antoine FANOU, Antoine Abel MISSIHOUN²*, Pierre SOVEGNON2, \\ Octave BEHOUNDJA-KOTOKO', Hugues BAIMEY and Clément AGBANGLA²
}

\author{
${ }^{1}$ Faculté d'Agronomie, Université de Parakou BP 123, Parakou, Bénin \\ 2Département de Génétique et des Biotechnologies, Faculté des Sciences et Techniques (FAST), \\ Université d'Abomey-Calavi, o1BP 526, Cotonou, Benin \\ *Corresponding author; e-mail: missihoun_antoine@yahoo.fr; Tél: +22995565684 / +229 97993806
}

\begin{tabular}{|c|c|}
\hline Article Info & ABSTRACT \\
\hline $\begin{array}{l}\text { Date of Acceptance: } \\
11 \text { February } 2019\end{array}$ & \multirow{6}{*}{$\begin{array}{l}\text { Chilli (Capsicum spp.) is a spice of economic importance and is widely cultivated for its } \\
\text { fruits in Benin. Viral infestations are one of the major constraints that hamper } \\
\text { agricultural production. The objective of the present work is to identify the viruses that } \\
\text { affect off-season pepper cultivated in the Donga Department in north west Benin. All } \\
\text { the communes of the Department were prospected and } 16 \text { fields were sampled. A total } \\
\text { of } 43 \text { pepper accessions with leaves showing symptoms of virus diseases were collected. } \\
\text { Six (6) phytovirus-specific primer pairs belonging to three botanical genera } \\
\text { (Begomovirus, Tobamovirus and Potyvirus) were used for molecular identification. The } \\
\text { results revealed the presence in the Department of Phytovirus of the genus } \\
\text { Begomovirus present on } 53.43 \% \text { of the accessions, the genus Potyvirus present on } \\
37.20 \% \text { of the accessions and at last the genus Tobamovirus present on } 6.97 \% \text { of the } \\
\text { accessions. The geographic distribution of the infestation remains globally high in all } \\
\text { communes of the Department with } 83.33 \% \text { of the accessions in Copargo; } 65.2 \% \text { in } \\
\text { Bassila, 53.83\% in Djougou, and } 75 \% \text { in Ouake. These results are significantly } \\
\text { important for the definition of an improvement policy of off-season chilli production by } \\
\text { setting up a program to control viral diseases. }\end{array}$} \\
\hline $\begin{array}{l}\text { Date of Publication: } \\
\text { o6 March } 2019\end{array}$ & \\
\hline Keywords & \\
\hline $\begin{array}{l}\text { Capsicum spp. } \\
\text { Chilli production }\end{array}$ & \\
\hline Off-season crops & \\
\hline Viral identification & \\
\hline
\end{tabular}

\section{Introduction}

Agricultural productivity improving is one of the major concerns in sub-Saharan Africa to save food security (Assogba-Komlan et al., 2009). In Benin, agricultural production can cover more than $80 \%$ of national food needs. Nevertheless, this production still faces to many constraints with consequent food insecurity. Truck farming has become an activity that responds effectively to urban food demand (Assogba-Komlan et al.,
2009). Truck farming products are common in people's eating habits. Based on the production, peppers are the second largest truck farming crop after tomatoes (FAO, 2014). It belongs to the genus of Capsicum and Solanaceae family. Its order is Solanales of Dicotyledonous class and Magnoliophyta phylum (Adetula and Olakojo, 2006; Dagnoko et al., 2013). It is a spice widely grown in the world. In Benin, it is grown in almost all Departments. Pepper is cultivated in normal season and counter season. It is produced in home 
gardens, perimeters of agricultural development, in mono-culture or in association with other crops such as tomato, corn, peanut, cowpea, soy, cassava, yam, etc.

The importance of peppers in human nutrition is crucial (Adetula and Olakojo, 2006). Leaves, fruits and roots are all used in sauce preparation (Assogba-Komlan et al., 2009). Chili can be eaten fresh, fried, in sauce or canned. It is often combined with other vegetables. Also known for its medicinal properties, the fruits of Capsicum spp. are used in traditional medicine for their antimicrobial properties due to the secondary metabolites they contain (Jin et al., 2009). Despite all these potentialities, the pepper crop remains subject to many biotic constraints (insect pests, various infectious diseases) and abiotic constraints that cause significant yield losses. In Benin, it is currently noted, an emergence of viral diseases that cause yield losses estimated at nearly 90\% (Orobiyi et al., 2013). The improvement of the production of this important species becomes an urgent action. In the first step, it is needed to identify the viruses that affect the crop to control their expansion. The general objective of this work is to identify some groups or species of viruses that affect the pepper crop in Western North of Benin.

\section{Materials and methods}

\section{Area of study and survey}

This study took place in four townships (communes) of Donga Department: Djougou, Bassila, Copargo and Ouaké (Fig. 1). This Department covers an area of $11,126 \mathrm{~km}^{2}$. It has 177 villages in the four townships. It constituted of 26 districts and located in Western North Benin with Djougou as capital. It belongs to agro-ecological zone IV characterized by tropical climate. Fourteen villages were selected according to their areas of pepper production and high virus incidence in the zone. In total, 16 fields were surveyed. In each field, the severity was recorded on 15 randomly selected plants expressing pepper virus symptoms (Fanou et al., 2017).

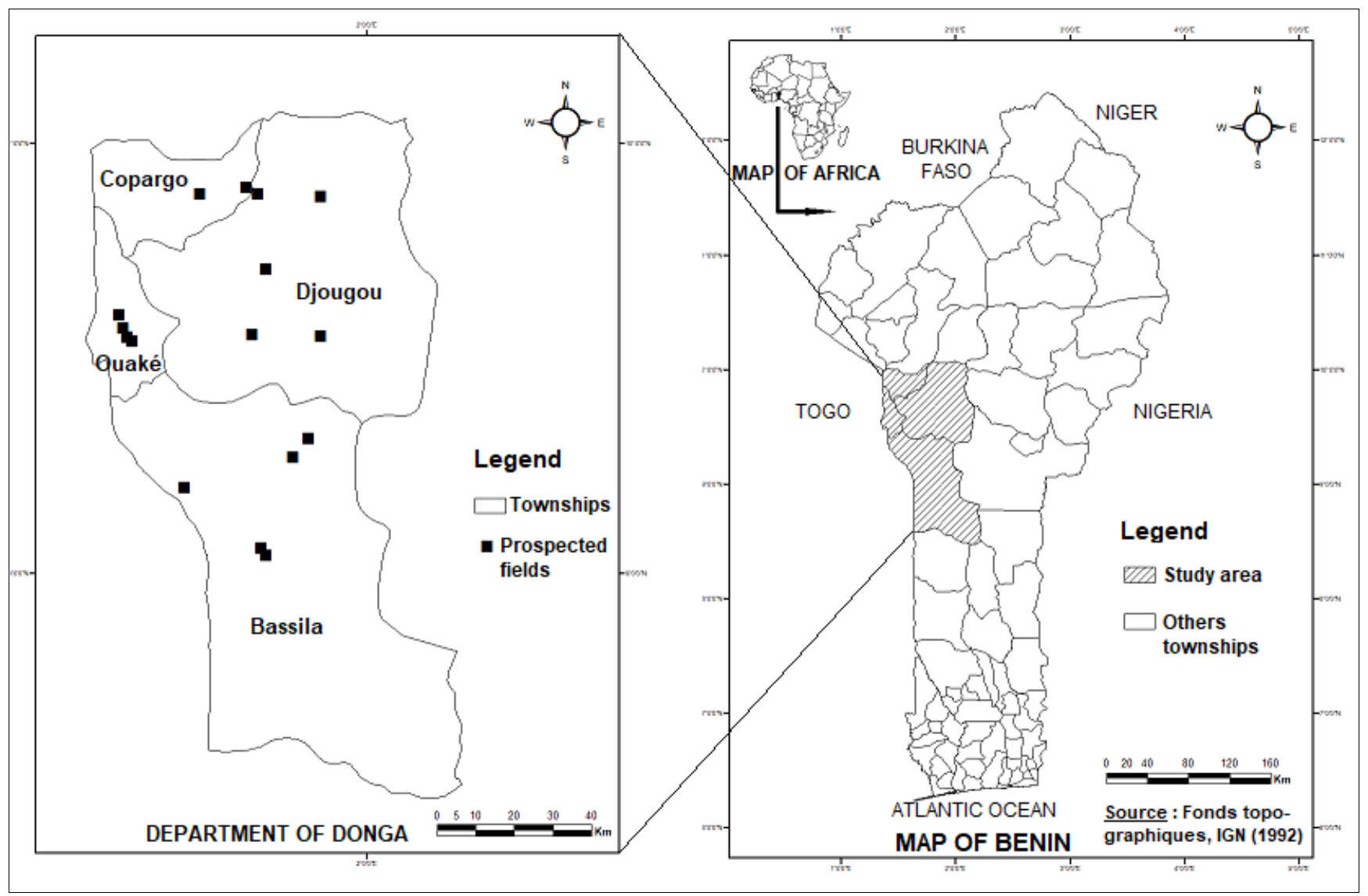

Fig. 1: Maps showing the geographical location and the fields surveyed for the study. 


\section{Plant material}

The plant material used consists of forty-two (42) leaves samples of young pepper accessions showing virus symptoms collected in different fields surveyed. The collected leaves were kept in aluminum paper and chilled until they were back to the laboratory.

\section{DNA extraction}

Total genomic DNA is isolated from the collected infected pepper leaves using the protocol described by Dellaporta et al. (1983) with minor modifications. In summary, (i) About $0.2 \mathrm{~g}$ of leaf sample was crushed in $500 \mu$ l of extraction buffer (50 $\mu \mathrm{l}$ TrisHCl with $\mathrm{Ph}=8.0,8.5 \mu \mathrm{l}$ of EDTA $0.5 \mathrm{M}$ and $5 \mu \mathrm{l}$ of $\beta \mathrm{ME} \mathrm{100 \% );} \mathrm{(ii)} \mathrm{Add} 33 \mu \mathrm{l} 20 \%$ SDS in each tube, (iii) Brief vortex the mixture and incubate at $65{ }^{\circ} \mathrm{C}$ in water bath for $10 \mathrm{~min}$; (iv) Add $160 \mu \mathrm{l}$ of potassium acetate to the cool mixture, vortex and centrifuge at 10,000 rpm for $10 \mathrm{~min}$; (v) Transfer the supernatant to a new sterile eppendorf tube containing $200 \mu \mathrm{l}$ of cold isopropanol and incubate at $4{ }^{\circ} \mathrm{C}$ for $20 \mathrm{~min}$, centrifuge the solution at $10,000 \mathrm{rpm}$ for $10 \mathrm{~min}$ to precipitate the DNA; (vi) Remove the supernatant, wash the DNA pellet with $500 \mu$ of $70 \%$ ethanol and dry the DNA at room temperature; (vii) Dissolve the DNA in $50 \mu \mathrm{l}$ of TE buffer and stored at $-20{ }^{\circ} \mathrm{C}$ until further use.

\section{Polymerase chain reaction (PCR) amplification and specific primers used}

Polymerase chain reaction amplifications were carried out in $25 \mu \mathrm{l}$ reaction consisting $3 \mu \mathrm{l}$ of template DNA, $2.5 \mu \mathrm{l}$ of $10 \mathrm{X} \mathrm{HCl}$ buffer, $2.5 \mu \mathrm{l}$ of each primer ( $\mathrm{F}$ and $\mathrm{R}$ ). ), $1.25 \mu \mathrm{l}$ of $\mathrm{MgCl}_{2}, 0.75 \mu \mathrm{l}$ of dNTPs, $0.75 \mu \mathrm{l}$ of Taq polymerase and ultrapure water (Meck water). The reactions are carried out in Peltier-Effect Cycling thermocycler according to a specific amplification program for each primers (Eman et al., 2006; Mnari-Hattabe et al., 2006; El-Araby et al., 2009; Fajinmi et al., 2011).

Four genera and five species of plant virus that generally affect Solanaceae specifically pepper crop were targeted in the study. These are Begomoviruses, Potexvirus, Tobamoviruses and Potyviruses. Specifically, these are three Potyviruses (Pepper mottle virus, Pepper veinal mottle virus, Potato virus Y), a Tobamovirus (Pepper Mild-Mottle Virus) a Potexvirus (Potato virus $\mathrm{X}$ ) and Begomoviruses in general (Eman et al., 2006; Mnari-Hattabe et al., 2006; El-Araby et al., 2009; Fajinmi et al., 2011). The specific primers used are summarized in Table 1. The revelation of PCR products was made by using Ethidium Bromide (BET) on a transilluminator (high performance) after electrophoresis on $2 \%$ agarose gel.

Table 1. List of pepper virus tested and primers used.

\begin{tabular}{|c|c|c|c|c|}
\hline $\begin{array}{l}\text { Virus } \\
\text { (acronyme) }\end{array}$ & Name & Genera & Primer & $\begin{array}{l}\text { Size } \\
\text { (bp) }\end{array}$ \\
\hline PepMoV & $\begin{array}{l}\text { Pepper mottle } \\
\text { virus }\end{array}$ & Potyvirus & $\begin{array}{l}\text { P3 }:(5 \text { 'AATGCAAAGCCAACATTC-3') } \\
\text { M4 : (5'CTAATACGAACACCAAGCAT-3') }\end{array}$ & 345 \\
\hline PMMoV & $\begin{array}{l}\text { Pepper Mild- } \\
\text { Mottle Virus, }\end{array}$ & $\begin{array}{l}\text { Tobamo- } \\
\text { virus }\end{array}$ & $\begin{array}{l}\text { P12/3 : (5'-ACAgCgTTTggATCTTAgTAT-3') } \\
\text { P12/3A (5'gTgCggTCTTAATAACCTCA-3') }\end{array}$ & 836 \\
\hline PVMV & $\begin{array}{l}\text { Pepper } \\
\text { veinalmottle } \\
\text { virus }\end{array}$ & Potyvirus & $\begin{array}{l}\text { 5'(TC(G/A/T/C)A(T/C)CAT(G/A/T/C)ACCCACAT(G/A/T/C)CC }{ }^{\prime} \\
\text { 5' ATGGTiTGGTG(T/C)AT(A/T/C)GA(G/A)AA(T/C)GG)3' }\end{array}$ & 650 \\
\hline PVX & Potato virus $X$ & Potexvirus & $\begin{array}{l}\text { v1 : S 5'GAYACNATGGCNCARGCNGCNTGG3' } \\
\text { c2 : AS 5' YTGNGCNGCRTTCATYTCNGCYTC 3'. }\end{array}$ & 300 \\
\hline PVY & Potato virus $Y$ & Potyvirus & $\begin{array}{l}\text { S: 5'TCAAGGATCCGCAAATGACACAATTGATGCAGG 3' } \\
\text { AS: 5’AGAGAGAATTCATCACATG1TCITGACTCC 3' }\end{array}$ & 801 \\
\hline $\begin{array}{l}\text { Begomo- } \\
\text { virus }\end{array}$ & & $\begin{array}{l}\text { Begomo- } \\
\text { virus }\end{array}$ & $\begin{array}{l}\text { S : 5'AATGCAAAGCCAACATTCGTTAGTGCTGC-3') } \\
\text { AS : (5'CTAATACATACGATCGTCGTAGTCGAACACCAAGCAT-3') }\end{array}$ & $\begin{array}{l}700- \\
800\end{array}$ \\
\hline
\end{tabular}




\section{Data analysis}

The presence and absence of specific band were respectively correlated to an infected plant or non virus-infected plant or the corresponding virus in order to calculate the percentage of infected sample per commune and to assess the infection of viruses and genera of viruses tested in the study area. Infection of the viruses in the collection was correlated with the different pepper genetic groups in the study area.

\section{Results and discussion}

Molecular identification of viruses reveals the presence of four targeted genera with specific size bands (Fig. 2). These are Begomoviruses detected on $53.43 \%$ of the samples, Potyviruses on $32.57 \%$ of the samples, Potexviruses detected on $4.65 \%$ and Tobamoviruses present on $6.97 \%$ of the collected samples (Table 2).

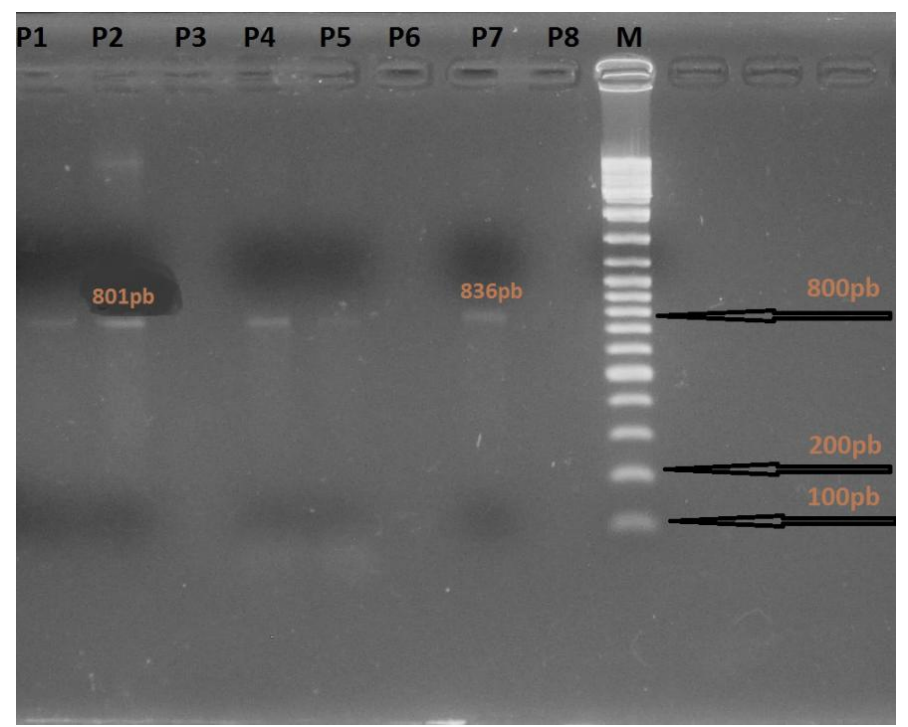

Fig. 2: Agarose gel electrophoresis 2\% identification of PMMoV (836 bp) and PVY (801 bp) viruses.

Table 2. Percentage of infections by viruses and virus genus.

\begin{tabular}{lll}
\hline Virus & Genus & $\begin{array}{l}\text { Infection by } \\
\text { genus (\%) }\end{array}$ \\
\hline PVMV & Potyvirus & 32.57 \\
PepMoV & \\
PVY & \\
PVX & Potexvirus & 4.65 \\
PMMoV & Tobamovirus & 6.97 \\
Begomovirus & Begomovirus & 53.43 \\
\hline
\end{tabular}

This identification shows that pepper crop of counter-season in Donga is infected by viruses of four genera. Similar results have been obtained in Egypt (Eman et al., 2006); in Tunisia (MnariHattab et al., 2006); in Nigeria (Fajinmi et al., 2011); in Egypt (El-Araby et al., 2009). Also, Tiendrebeogo in 2010 by working on the characterization and epidemiological aspect of Begomoviruses infesting the vegetables and the cassava in Burkina Faso has detected Potyviruses, Tobamoviruses and Begomoviruses on peppers (Capsicum annum and Capsicum frutescens). In addition, the first work concerning the identification of tomato and peppers viruses grown in north east of Benin using ELISA tests showed seven viruses grouped in the genus of Cucumovirus, Tobamovirus, Potyvirus and Begomovirus (Afouda et al., 2013). The surveys conducted by these authors both in dry season and rainy season did not show a significant difference for the kinds of viruses infecting the pepper. In our study, Potato Virus X (PVX) (genus: Potexvirus), was detected while Afouda et al. (2017) detected viruses of the genus Cucumovirus and the genus Polerovirus during the survey in southern and north east Benin. These results show that peppers grown in Benin whatever the season may be infected by several kinds of viruses. The large detection of Begomoviruses in this study may be explained by the fact that pepper crop in Donga Department are mostly associated with other crops such as cassava and tomato which are highly susceptible to Begomoviruses (Kabemba et al., 2017). Indeed, Begomoviruses infect many dicotyledonous plant species and cause enormous economic damage in many highly cultivated plants such as tomato, bean, cassava and cotton. The low presence of Potyvirus and Potexvirus Tobamovirus compared to Begomovirus is explained by the fact that in the present study, Begomovirus primers are not specific to a particular type of virus but detect all virus of the genus unlike the genus Tobamovirus, Potexvirus and Potyvirus where the primers detected a specific virus. Two of three virus species targeted of Potyvirus, Potexvirus and Tobamovirus targeted in this study were found to be present on the infected plants. This is for Potyvirus, Pepper Mottle Virus (PepMoV), and Potato Virus Y (PVY); for Potexvirus, Potato Virus X (PVX) and for Tobamovirus, Pepper Mild Mottle Virus (PMMoV). In total, of five targeted virus species, four were 
found to affect the pepper crop in Donga Department. The degree of infestation varied from one species of virus to another. It is $20.93 \%$ for Pepper Mottle Virus, 11.62\% for Potato Virus Y, 6.97\% for Pepper Mild Mottle Virus and 4.65\% for Potato Virus X.
Regarding the geographical distribution of these viruses, it is presented in all the townships of the Department or $83.33 \%$ of the sample collected in Copargo, $75 \%$ of the sample of Ouaké, out of 62.5 $\%$ of the Bassila sample and finally $53.83 \%$ of the Djougou samples (Table 3).

Table 3. Proportion of infected sample with viruses and virus genus identified by township.

\begin{tabular}{llll}
\hline Townships & Number of sample & Infected samples & Infection proportion (\%) \\
\hline Bassila & 16 & 10 & 62.5 \\
Djougou & 13 & 7 & 53.84 \\
Copargo & o6 & 5 & 83.33 \\
Ouake & o8 & 6 & 75 \\
Total & $\mathbf{4 3}$ & $\mathbf{2 8}$ & $\mathbf{6 5 . 1 1}$ \\
\hline
\end{tabular}

This important distribution could be explained to the horizontal transmission either by wind or by vectors such as insects as reported by Yao et al. (2013). Known symptoms of these viruses include mosaic, curling leaf curl, leaf curl and foliar shrinkage (Fanou et al., 2017), which at the score 0.05 show high severity in Pepper field of Donga. Of the twenty-eight sample revealed infected by the viruses tested, eighteen (18) or $64.28 \%$ belong to genetic group I (Group I) and the other ten (10) or 35.11\% belong to the second genetic group (Group II) from the molecular genetic characterization of the sample (Fanou et al., 2017). This strong presence of viral diseases in group I could be explained by the high presence in this group of C.chinense species (65.55\%) which is more susceptible to viruses than $C$. annuum and $C$. frutescens species present in group II (Mahbou, 2010).

\section{Conclusion}

This study revealed the presence of Pepper mottle virus (PepMoV), Potato virus Y (PVY), Potato virus $\mathrm{X}$ (PVX) among the viruses that affect pepper crop in Donga Department belonging to the group of Potyviruses and Pepper Mild-Mosaic Virus (PMMoV) belonging to the group of Tobamoviruses. In general, the study also revealed the presence of Begomovirus genus. The degree of infestation of these viruses varied by species and by genus. The infestation also varied according to the groups of pepper varieties. Thus, the genetic group I essentially characterized by accessions of the species $C$. chinense is more susceptible than the genetic group II characterized by $C$. annuum and $C$. frutescens species. For a better productivity of the pepper production in Donga department other research actions should be undertaken:

$\checkmark$ the identification of specific strains of viruses of the Begomovirus group affecting pepper crops

$\checkmark$ the identification of other virus genus and species that affect pepper crops;

$\checkmark$ the extension of this study to the other departments in Benin where pepper is practiced in order to develop an integrated biological control strategy;

$\checkmark$ the development of a policy to promote pepper cultivation by setting up a virus eradication program.

\section{Conflict of interest statement}

Authors declare that they have no conflict of interest.

\section{Acknowledgement}

The authors acknowledged the Project NICHE BEN-172 for contributing to accomplishment of this study, Doctor Achille DEDJIHO and $\mathrm{Mr}$. SEDAH Paulin, PhD student in the Department of Genetics and Biotechnology for the laboratory technical assistance.

\section{References}

Adetula, O., Olakojo, A., 2006. Genetic characterization and evaluation of some pepper accessions Capsicum frutescens (L.): The Nigerian 'Shombo' collections. Amer.-Eur. J. Agric. 1(3), 273-281.

Afouda, L., Kone, D., Zinsou, V., Dossou, L., 
Kenyon, L., Winter, S., Knierim, D., 2017. Virus surveys of Capsicum spp. in the Republic of Benin reveal the prevalence of pepper vein yellows virus and the identification of a previously uncharacterised polerovirus species. Arch. Virol. 162(6), 1599-1607.

Afouda, L.A.C., Kotchofa, R., Sare, R., Zinsou, V., Winter, S., 2013. Occurrence and distribution of viruses infecting tomato and pepper in Alibori in northern Benin. Phytoparasitica. 41, 271-276.

Assogba-Komlan, F., Sikirou, R., Sodjinou, E., Mensah, A., 2009. Production durable du piment au Bénin. MAEP/INRAB. Référence technico-économique de la production agricole. 48p.

Dagnoko, S., Yaro-Diarisso, N., Sanogo, P. N., Adetula, O., Dolo-Nantoumé, A., GambyTouré, K., Traoré-Théra, A., Katilé, S., DialloBa, D., 2013. Overview of pepper (Capsicum spp.) breeding in West Africa. Afr. J. Agric. Res. 8(13), 1108-1114.

Dellaporta, S. L., Wood, J., Hicks, J. B., 1983. Isolation of DNA from higher plants. Plant Mol. Biol. Rep. 4, 19-21.

El-Araby, W. S., Ibrahim, I. A., Hemeida, A. A., Mahmoud, A., Soliman, A. M., El-Attar, A. K., Mazyad, H. M., 2009. Biological serological and molecular diagnosis of three major potato viruses in Egypt. Int. J. Virol. 5(2), 77-88.

Eman, A. H., 2006. Biological, serological and molecular detection of pepper mottle virus infecting pepper plants in Egypt. J. Phytopathol. 34, 121-138.

Fajinmi, A. A., Odebode, C. A., Fajinmi, O. B., 2011. The effect of agro-ecological zones on the incidence and distribution of aphid vectors of pepper veinal mottle virus, on cultivated pepper (Capsicum annum L.) in Nigeria. J. Central Eur. Agric. 12(3), 528-542.

Fanou, A., Baimey, H., Behoundja-Kotoko, O., Dedjiho, A., Missihoun, A., Sovegnon, P., Agbangla, C., 2017. Distribution et importance des symptômes de viroses du piment
(Capsicum spp.) de contre saison dans le Département de la Donga au nord-Bénin et caractérisation moléculaire des accessions. Ann. UP Série Sc. Nat. Agron. Décembre 2017; $7(1), 32-40$.

FAO, 2014. FAOSTAT Database. Food and Agriculture Organization, Roma, Italy. Available online at URL: www.fao.org

Jin, R., Pan, J., Xie, H., Zhou, B., Xia, X., 2009. Separation and quantitative analysis of capsaicinoids in Chili peppers by reversedphase argentation LC. Chromatographia 70 (56), 1011.

Kabemba, N., Kadina., Gikug., Munganga, J., Otono, F., Bulubulu, F., Hity., 2017. Incidence et sévérité de la mosaïque africaine du manioc dans les champs et les jardins de case à Kinshasa. Tropicultura 35(4), 173-179.

Mahbou-Somo-Toukam, G., 2010. Diversité de Ralstonia solanacearum au Cameroun et bases génétiques de la résistance chez le piment (Capsicum annum) et les Solanacées. Amélioration des plantes. Agro Paris Tech.

Mnari-Hattab, M., Ezzaier, K., 2006. Biological, serological, and molecular characterization of Pepper mild mottle virus (PMMoV) in Tunisia. Tunisian J. Plant Prot. 1, 1-12.

Orobiyi, A., Dansi, A., Assogba, P., Loko, L. Y., Dansi, M., Vodouhè, R., Akouègninou, A., Sanni, A., 2013. Chili (Capsicum annum L.) in southern Benin: Production constraints, varietal diversity, preference criteria and participatory evaluation. Int. Res. J. Agric. Sci. Soil Sci. 3(4), 107-120.

Tiendrebeogo, F., 2010. La caractérisation et aspects épidémiologiques des Begomovirus infectant les plantes maraîchères et le manioc au Burkina Faso. Thèse de Doctorat Unique. Université de Ouagadougou, Burkina Faso. 154 p.

Yao, M., Li, N., Wang, F., Ye, Z., 2013. Genetic analysis and identification of QTLs for resistance to cucumber mosaic virus in Chili pepper (Capsicum annuum L.). Euphytica 193, $135-145$.

\section{How to cite this article:}

Fanou, A. A., Missihoun, A. A., Sovegnon, P., Behoundja-Kotoko, O., Baimey, H., Agbangla, C., 2019. Molecular genetic identification of viruses affecting pepper crop (Capsicum spp.) in Western North of Benin. Int. J. Curr. Res. Biosci. Plant Biol. 6(3), 9-14. doi: https://doi.org/10.20546/ijcrbp.2019.603.002 